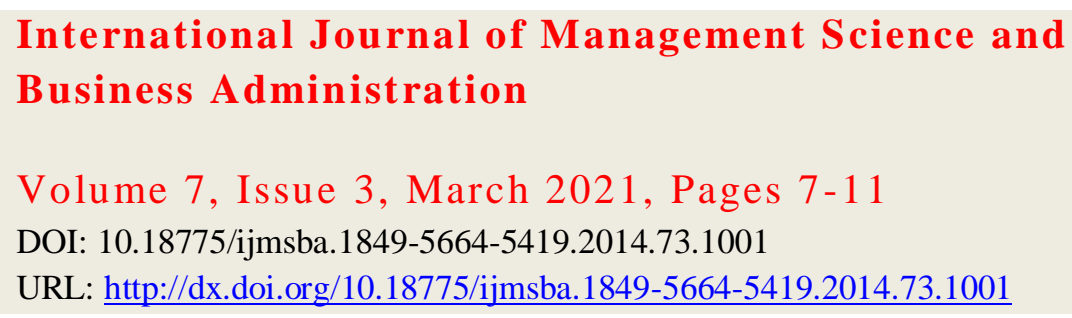

\title{
Further Development of a New Concept in Small Scale Forestry: "Forest-Management-Service-Contracts" in Bavaria
}

\author{
Dr. Michael Lutze \\ Department of Forest technology, Economics and Timber; \\ Bavarian State Institute of Forestry, Freising, Germany
}

\begin{abstract}
The forests in Bavaria cover about one third of its land area or 2.56 Mio hectares (ha) and the major part of this forest is held by private forest owners. Around 700000 landlords manage approximately 1.4 Mio ha. In Bavaria, about 130 Forest Owner Associations (FOAs) play a key role in managing the small scale forests. In the last years, a new concept in small scale forest management arose, "Forest-Management-Service-Contract" (FMSC). The statutory corporations needed a proper management for their forests accordingly the German forest laws and the FOA took the chance to adopt a new business concept. In Bavaria exist about 3000 forest-management-service-contracts, covering over 40.000 hectares. In a current project "Further development of the successful concept - Forest-Management-Service-Contracts through economic analysis" will be elaborated a data base for the better understanding of the crucial to success factors of FMSC. The economic analysis of the FMSC will base on business process analysis related to the administration of FMSC, on economic operating figures deviated from a single contract analysis and performance data. This information base aims to optimize the contracting process and to reduce the risks related to unknown hazards of the single FMSC.
\end{abstract}

Keywords: Small scale forestry, Forest owner association, Forest-management-service-contract, Business process analysis

\section{Introduction}

The forests in Bavaria cover about one third of its land area or 2.56 Mio hectares (ha) and the major part of these forests are held by private forest owners. Around 700000 landlords manage approximately 1.4 Mio ha. Two thirds of the private forest enterprises cover less than 20 ha. In Bavaria, about 130 Forest Owner Associations (FOAs) play a key role in managing the small scale forests.

In the last years, a new concept in small scale forest management arose. The background is:

1. A considerable part of the forest owners is not able or willing to manage their forest by themselves. The reasons could be described as "social demographic changes in modern societies". That means forest owners are overage and /or physically unable to work or deal with the management of their property, they do not have the skills and expertise, or they live to far from their forest property (urban forest owners).

2. In 2005, according to a "reform" of the Forest Service in Bavaria, the Forest Service reduced the subsidised management service for statutory corporations (those are for example: church as forest owner, municipalities and common land bodies).

In this situation a "new market" for forest management services arose. The statutory corporations needed a proper management for their forests according to the German forest laws and the FOA took the chance to adopt a new business concept, the "Forest-Management-Service-Contract" (FMSC). The Bavarian Forest Service has reduced the subsidies for the statutory corporations on one side, and started supporting the FOA on the other side, to incentivise them to fill this market niche. 
In Bavaria, approximately 3000 Forest-Management-Service-Contracts exist at the present, covering over 40.000 hectares. For about $20 \%$ of the FOAs, FMSCs are already a significant business segment. The FOAs supervise on average, more than 500 hectares each and contract professional forest engineers (Suda, Schaffner, Huml 2009).

The subsidies for the FOAs in the framework of the development of the FMSC concept are regulated in the "directive of subsidies for project measures of forest owner associations within the frame of a forestal support programme". For a better understanding of the development of FMSCs, some important facts of this directive are summarized:

I. The »basic-supervision« (which is a precondition to receive the »state subsidies «) includes: a) forest protection and b) legal duty to maintain safety. Further agreements between the parties are possible, independently of the state directive.

II. Subsidies depending on FMSC areas:

\begin{tabular}{|l|l|}
\hline Area of FMSC & Subsidies \\
\hline $0,1-2$ ha & $70 €$ per contract and year \\
\hline$>2$ ha & Single case calculation, see figure 1 \\
\hline
\end{tabular}

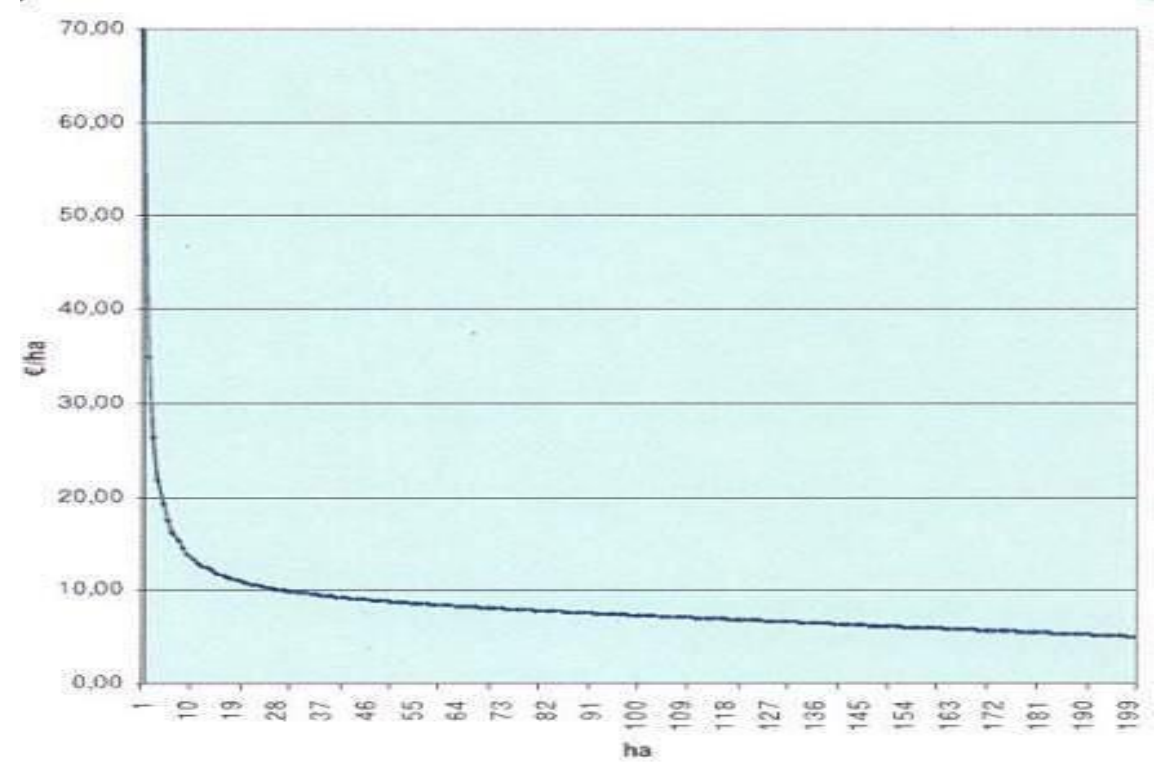

Figure 1: Subsidies for FMSC related to contract area in $€$ per year (STMLF, 2007)

Figure one shows the declining state subsidies as a function of the total FMSC area. This financial incentive fosters the development of FMSCs, but the FOAs still must analyse every single contract to estimate its cost-benefit-ratio. The intended project "Further development of the successful concept - Forest-Management-Service-Contracts - through economic analysis" will support the FOAs in this point and will contribute to facilitate this economic analysis. The main objective of the project will be: Elaboration of a data base for the better understanding of crucial factors of FMSCs success. Since there are no sound economic data available to verify the profitability of single FMSCs, the participating FOAs will be able to improve their decision making. The economic analysis will be based on business process analysis related to the administration of single contracts on economic operating figures deviated from single contract analysis and performance data. This information base aims to optimize the contracting process and to reduce the risks related to unknown hazards of the single FMSC.

The main partners of the actual ongoing preliminary study as well as the partners of the intended project are the FOAs and the Bavarian Forest Service. The Forest Service works traditionally close together with the FOAs and supports them especially with extension work for the forest small holders. 


\section{Methodology}

The applied methodology is orientated strictly at the objectives of the study. Thus a) participatory methods of empirical social research are used to analyse business processes related to FMSCs, b) quantitative analysis serve to document and process the individual working time of FOA-staff members used for single working steps within the FMSC business process, c) single FMSCs are analysed for concrete economic information (revenue and costs) and are put in relation to the forest structure of the contract area and d) in workshops, the project team applies methods like SWOT (strength, weaknesses, opportunities and threats) to analyse the FMSCs and develop the concept for future benefits for the forest owners as well as for the FOAs (Gaitanides 2007); (Lutze, Neuner 2010b).

\section{Results}

First results of the preliminary study show, that the crucial factors for success vary because of natural or regional characteristics like tree species, age, potential hazards and size of contract area.

\subsection{Revenues from Forest-Management-Service-Contracts}

In principle, revenues from FMSCs are based on three pillars: I) the state subsidies (see point 1), II) direct payments of the forest owner for fixed annual services or services on demand and III) indirect revenues (service charges) from harvesting and marketing measures on the contracted area. An example of the FOA, called "Lower Bavaria", may clarify the basic supervision as combined in the contract and the revenues from piles II. and III.:

A) The basic supervision includes the following, inter alia:

- General administration and accounting

- Mentoring/counseling/advisory service in silviculture

- Forest protection (controlling and realisation of measures)

- Annual reporting

- Legal duty to maintain safety

B) Revenues from the basic supervision:

○ $25 € /$ ha/year

- Additional services, in accordance with the forest owner:

- Realised by a forest engineer: $35 € /$ hour

- Realised by qualified forest worker: $25 € /$ hour

- Realised by non-skilled worker: $15 € /$ hour.

In case of additional controlling measures (more than two) due to calamities, for example because of bark beetles, these measures will be paid like additional services. Travel expenses are recompensed at $0.32 € / \mathrm{km}$.

C) Revenues from wood harvesting and marketing:

$\circ 4 \%$ of gross selling price (provision)

This brief analysis shows that the main regular possible revenues are already determined by the contract. Additional or variable revenues can be expected from wood harvesting and marketing, thus from the core process of the FOAs (Lutze, 2010). But these desired, additional revenues depend on the forest estate itself (species, age, growing stock and so on) as well as on the owner objectives and the wood market.

\subsection{Working times for single FMSC}

The results of working times documentations for single FMSCs show a clear tendency: The smaller the total area of a single contract is, the higher the time effort per hectare. For FOAs, that means that they should analyse accurately in what kind of work they invest their time (productive work or service hours for forest protection or legal duty to maintain safety e.g.). 


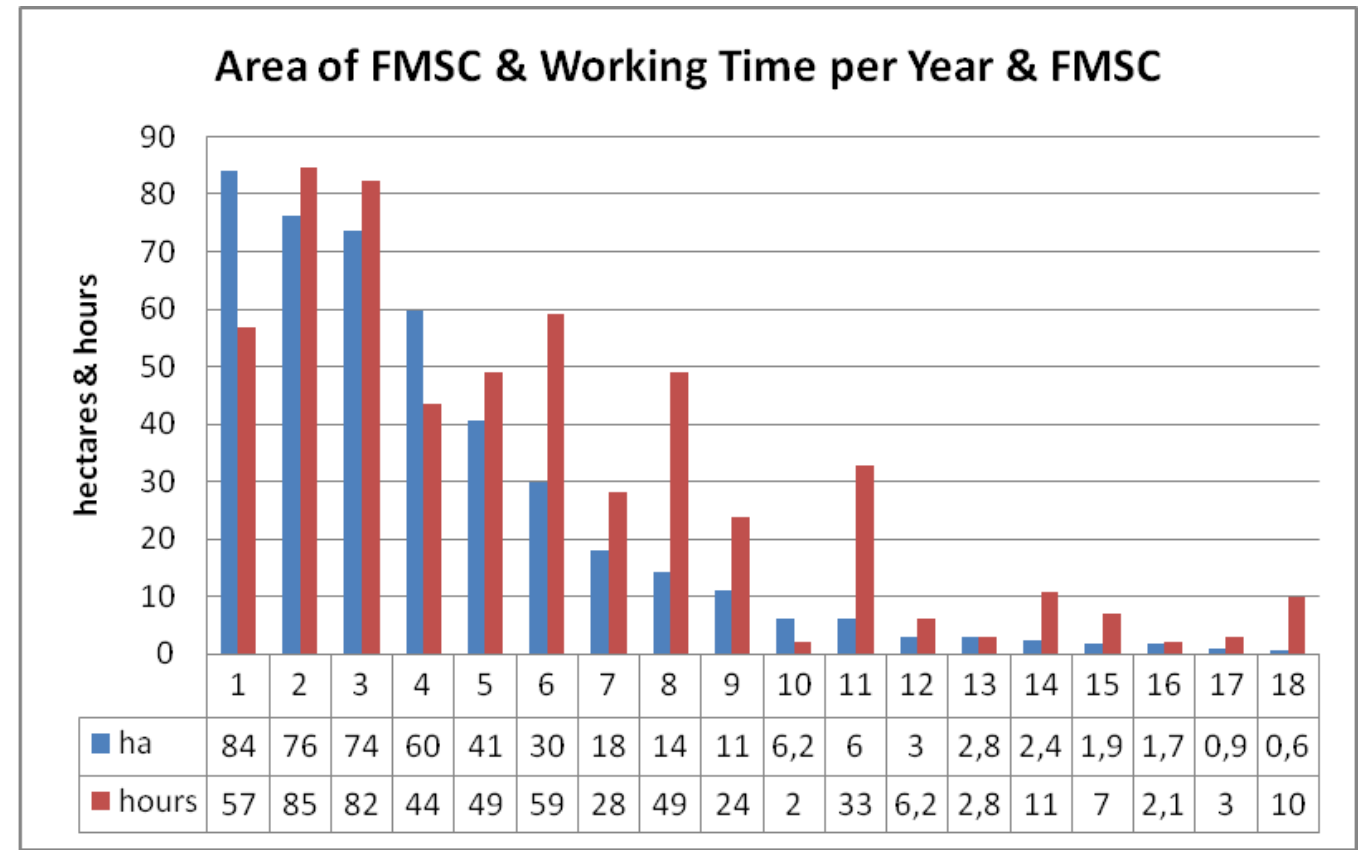

Figure 2: Areas of single Forest Management Service Contracts (FMSC) and the invested working time per year

\subsection{SWOT Analysis}

The so-called SWOT analysis is a very suitable method to identify strengths, weaknesses and threats as well as opportunities for the FOA within the scope of their FMSCs. In a workshop with an FOA, the following examples were elaborated, and they partially underline the above analysed risks of time consuming non-profitable activities. Moreover, the examples summarize further critical points and chances for the FOA (see table next page).

Table 1: SWOT analysis of the FMSCs of the FOA $»$ Lower Bavaria $«$

\begin{tabular}{|c|c|}
\hline Strengths & Weaknesses \\
\hline $\begin{array}{l}\text { FOA is present locally, that means »trust \& security« } \\
\text { for the forest owners }\end{array}$ & $\begin{array}{l}\text { Model contract: The FOA must accomplish defined and } \\
\text { contractual fixed activities for fixed prices }\end{array}$ \\
\hline \multicolumn{2}{|l|}{$\begin{array}{l}\text { The forest owners have confidence in the work of the } \\
\text { FOA }\end{array}$} \\
\hline \multicolumn{2}{|l|}{$\begin{array}{l}\text { In the group of so called „urban forest owners”, circa } \\
1 / 3 \text { are women. So, to have a female forest engineer for } \\
\text { this field is advantageous }\end{array}$} \\
\hline \multicolumn{2}{|l|}{$\begin{array}{l}\text { Professional business process of the Core Process } \\
\text { "Wood Supply and Marketing" }\end{array}$} \\
\hline \multicolumn{2}{|l|}{$\begin{array}{l}\text { Enough professional forest engineer within the staff, } \\
\text { logical distribution of duties and responsibilities }\end{array}$} \\
\hline \multicolumn{2}{|l|}{$\begin{array}{l}\text { Reliable collaboration with the local adviser of the for- } \\
\text { est administration }\end{array}$} \\
\hline Opportunities & Threats \\
\hline $\begin{array}{l}\text { A presence in the private forests can lead to further } \\
\text { contracts (marketing) }\end{array}$ & Missing cost-benefit analysis; reliable data do not exist \\
\hline $\begin{array}{l}\text { Synergies: Harvesting and wood marketing in one pri- } \\
\text { vate forest estate can motivate the neighbors to ask the } \\
\text { FOA to execute the same services on their land }\end{array}$ & $\begin{array}{l}\text { Small forest areas }(\leq 1 \text { ha }) \rightarrow \text { high operational expendi- } \\
\text { ture? } \\
\text { Profitable for the FOA? }\end{array}$ \\
\hline \multirow[t]{3}{*}{$\begin{array}{l}\text { FMSC can contribute to a continuous wood supply and } \\
\text { marketing by the FOA }\end{array}$} & $\begin{array}{l}\text { To many nonpaid services (for the forest owner) are in- } \\
\text { cluded in the so called »basic-supervision« (which are } \\
\text { preconditions to receive the »state subsidies«) } \\
\text { Profitable for the FOA? }\end{array}$ \\
\hline & Faithfulness of forest owner successors is insecure \\
\hline & $\begin{array}{l}\text { Further development of state subsidies is } \\
\text { inexplicit }\end{array}$ \\
\hline
\end{tabular}




\section{Discussion}

The first analytic results of the preliminary study are demonstrating some risks and chances of Forest Management Service Contracts. In workshops and discussion with the managers of the involved FOAs such outcomes were underlined. Some points are discussed here:

1. The fixed revenues - composed of the state subsidies and the contractual payments - do not cover in all cases all costs related to the tasks determined by contract. This risk increases with declining contracting areas due to inefficient work in small forest areas and unknown threats from hazards, like calamities from bark beetles, damages through wind blasts and following high working input for reforestation and long periods without additional revenues from wood harvesting and marketing.

2. Some FOAs are speculating on additional or variable revenues through wood harvesting and marketing measures, even without further analysis and unsecure market outlooks or unknown forest owner objectives. Especially in small structured private forest estates such "gambling" can cause deficits (Lutze 2010c).

3. Some FOAs accepted in the past "all kinds" of forest areas for their portfolio of FMSCs as a "political" measure of the association to demonstrate to their members that they are willing and able to fulfill this desired concept by the state, to demonstrate to them that the association is able to cover this business and - maybe as the most important argument - to avoid that competing neighbor associations or private consulting firms gain parts of this market segment within the association's natural boundaries.

4. FOAs use the FMSC concept as a marketing tool by accepting all offered areas to gain attractive contracts with bigger forest areas.

5. Solutions for risk reduction can be especially found in contracting details:

a. Optimizing the contractual details: non profitable duties should be reduced to the minimum of "basicsupervision « (which is a precondition to receive the »state subsidies«). If the fixed revenues for the basic supervision do not cover the estimated costs, consideration should be given to refusing an offered contract or to increase the service charge individually depending on the contract circumstances.

b. Reducing the contract period or combining clauses to reduce the risks for the association, for example in case of certain hazards.

Up to now the FMSC is a success story as it contributes to the further professional development of FOAs and can raise the revenues of the FOA through fixed revenues or additional revenues. The concept also offers the opportunity to create new jobs at the FOA. The risks are manageable through further development of the contracts and optimization of related business processes. Because of unknown economic data and the short period of experience, further research on this concept is advisable.

\section{References}

- Gaitanides, M. (2007). Prozessorganisation; Entwicklung, Ansätze und Programme des Managements von Geschäftsprozessen. Verlag Franz Vahlen, München.

- Lutze, M. (2010). Bündeln, Vermarkten, Abwickeln. LWF aktuell 77.

- Lutze, M. (2010). Forest Owner Associations as Intermediaries between Forest Owners and the Wood Based Industry. IUFRO Conference "Small Scale Forestry in a Changing World".

- Lutze, M., \& Neuner, J. (2010). Mobilisierung von Rohholz und Weiterentwicklung der Holzerntekette Forstlicher Zusammenschlüsse in Bayern insbesondere durch die Anpassung von Geschäftsprozessen an neue Logistik- und Informationstechnologien. Projektbericht, Bayerische Landesanstalt für Wald und Forstwirtschaft.

- STMLF (2007). Richtlinie für Zuwendungen für projektbezogene Maßnahmen der forstlichen Zusammenschlüsse im Rahmen eines forstlichen Förderprogramms. Bekanntmachung des Bayerischen Staatsministeriums für Landwirtschaft und Forsten .

- Suda, M., Schaffner, S., \& Huml, G. (2009). Projekt G 28. Die Beratung der Forstlichen Zusammenschlüsse in Bayern - Inhalte, Methoden und Erfolge. TUM, Freising. 